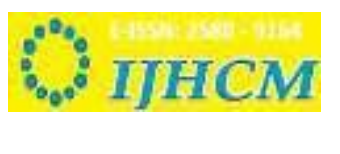

\title{
EFFECT OF WORK CULTURE AND LEADERSHIP ON TRUST IN PT. ASTRA AGRO LESTARI Tbk.
}

\author{
Pandapotan Sitompul \\ State University of Jakarta \\ Email: pandapotansitompul_im15s3@mahasiswa.unj.ac.id \\ Suparno Eko Widodo \\ State University of Jakarta \\ Email: suparnoeko@unj.ac.id
}

R. Madhakomala

State University of Jakarta

Email: madhakomala@unj.ac.id

\begin{abstract}
The purpose of this study was to study the effect of work culture, leadership on trust. The research process was carried out at PT. Astra Agro Lestari Tbk. uses a case study method. The study sample was 105 employees of PT. Astra Agro Lestari Tbk. selected in simple random sampling. The findings are: (1) there is a positive direct influence of work culture on trust, (2) there is a positive direct influence of leadership on trust, (3) there is a positive direct influence of work culture and hleadership together on trust. Referring to these findings, researchers can conclude that trust is positively influenced by work culture and leadership. Therefore, to maintain trust, organizations must implement a work culture and leadership. Finally, it was concluded that work culture and leadership must be considered in generating better trust.
\end{abstract}

Keyword: Trust, Work Culture, and Leadership

\section{INTRODUCTION}

Rahmani \& Heydari states that trust in addition to organizational commitment within the educational organization could have a positive impact on maintaining quality staff (Rahmani \& Heydari, 2017). Trust in addition to organizational commitment in the organization can have a positive impact on the maintenance of qualified employees. Trust also affects employee commitment. Decreasing employee confidence in the leadership and organization will result in decreased employee commitment. The higher the employee's trust in the company's leadership, it will improve employee professional competence, which has an impact on the employee's increased commitment. The employee assumes that his trusted person will fulfill all his duties properly, as expected from the perspective of psychology.

Based on observations in the field, PT Astra Agro Lestari applies the Corporate Culture (Honest and responsible, Triple S, Fanatic, Caring, Control, Repair and Innovation, Intention). Researchers see that the application of work culture has been managed quite well, but what indicators are declining from this work culture need to be investigated to find out what indicators are already strong and what indicators are still weak.

Plantation companies in general must have strong leadership because plantation companies use large amounts of human resources (labor intensive). Researchers observe leadership has an influence on trust because basically employees led by their superiors will follow what is conveyed and done by their leaders. Therefore it is necessary to see whether leadership also influences trust. 
This research generally aims to prove the influence of work culture and leadership on trust in PT. Astra Agro Lestari Tbk. In particular, this study aims to test whether or not there are:

1. Direct influence of work culture on trust

2. Direct influence of leadership on trust

3. Direct influence of work culture and leadership together on trust

The novelty in this study lies in the trust variable. Not many studies have examined the influence of work culture and leadership on trust, especially in plantation companies. This is a novelty that resulted from this research.

\section{LITERATURE REVIEW}

\section{Trust}

Trust is important in the organization, because without trust there may not be a harmonious relationship between leaders and subordinates. Experts try to define trust based on their conditions and points of view. McShane and \& Glinow said that trust refers to positive expectations one person has toward another person in situations involving risk (McShanes \& Von Glinow, 2008). For McShane \& Von Glinow, trust refers to a person's positive expectations of others in which there is certainly a risk. Trust means betting on trust in a person or group of people. It is also a reciprocal activity. That is, to get the trust of others, someone must also do it to others. Employees will take sides and be responsible for working with companies, if the employees put trust in their leaders. Sureyya said "organizational trust is considered as the most important element for the organizational productivity and commitment" (Sureyya, 2017). This means that organizational trust likened to the most important element for productivity and organizational commitment.

Luthans expressed a different opinion, "Trust is relationships make companies farmore reliant on each other" (Luthans, 2011) or trust is a relationship that depends on each other. Can be interpreted that trust is built by the existence of mutually bound relationships between one person and another. Meanwhile Rahmani \& Heydari states that, "trust, in addition to organizational commitment within the educational organization could have a positive impact on maintaining quality staff' (Rahmani \& Heydari, 2017). Based on the above opinion, trust in addition to organizational commitment in the organization can have a positive impact on maintaining quality employees.

According to Mullins, how can members of staff show that they can be trusted unless trust is first placed in them (Mullins, 2005). For Mullins (2005) trust is one of the needs of employees that must be fulfilled to generate excitement in work. Therefore, lack of trust will be very detrimental to the time and use of sources of income in the workplace. Managers who do not believe in their employees will only waste a lot of time by controlling each week for the use of sources of income in the workplace of their employees.

Based on the explanation of the concept above, it can be synthesized that trust is a willingness and positive expectation given to a person or group of authorities on the basis of mutual respect and respect based on interpersonal relationships in the hope of obtaining positive results also from those who are authorized.

The indicators of trust are (1) assignment of tasks, (2) completion of tasks, (3) team cohesiveness, (4) effective communication, (5) idea development, (6) justice, (7) responsibility, (8) support, (9) consistency, and (10) mutual respect.

\section{Work Culture}

In simple terms, work culture look as the implementation of cultural concepts in work or in a group. As stated by Schein the following: The culture of groups are now interpreted as patterns of shared basic assumptions that groups learn when they solve problems of adjustment with external parties and their internal integration, that was works well so it is considered valid because it must thaught for new members as the right way to understand, thing and feel in connection with the problem that exists (Schein, 2004). 
Based on the above opinion, the culture that develops in a group or organization is basic pattern of assumptions agreed upon, has been studied by group members in solving problems related to adjustments externally and internally integration. Culture develops because it has worked well so that it is which means valid therefore culture can taught for new members of the organization as right way to realize, think and feel relationships in dealing with group problems.

According to Nawawi, understanding of work culture is a habit that is carried out repeatedly by employees in an organization, violations of this practice are not strictly sanctioned, but morally organizational behavior has agreed that these habits are habits that must be adhered to in order to carry out work to achieve aim (Nawawi, 2003).

Where as according to Prasetya, the notion of work culture is a philosophy based on the view of life as a value that becomes traits, habits, and the power that drives, rooted in life a community group or organization reflected in attitudes to behavior, ideals, beliefs, actions and opinions incarnate as work or work (Prasetya, 2001). So work culture is an attitude and belief and trust from all members of organization in action that is real or working, because it contains values that form habits, and also is a strong encouragement. In organizations, functions or goals of work culture are as social glue in uniting members in achieving organizational goals in the form of provisions or values that must be said and done by its members. In addition, work culture also functions as a control over behavior of members of the organization.

Tylor (in Ndraha), stated "Culture or civilization from a broad ethnographic is a very complex whole that covers beliefs, knowledge, morals, arts, customs, laws and abilities and other habits acquired by individuals as members society". It cannot be denied the opinion of Tylor. Because work culture always involves many things, knowledge, beliefs, art, morality, law, customs and capabilities and other habits. All of them have their respective roles as part of the community in an organization (Ndraha, 1997). According to Ndraha, understanding of work culture is a group of basic thoughts or mental programs that can be used for improve work efficiency and human cooperation owned by a group of people.

According to Osborne \& Plastrik, work culture is a set of behavioral feelings and psychological frameworks that are deeply internalized and shared by members of the organization (Osborne \& Plastrik, 2002). In the opinion above that the work culture is reflected in attitudes towards work, and behavior at work.

Based on the explanation of the concept above, it can be synthesized that what is meant by understanding work culture is a system of values, perceptions, behaviors and beliefs held by each individual employee about the meaning of work and reflection in activities to achieve organizational goals. The indicators are (1) hard work, (2) discipline, (3) productive, (4) responsibility, (5) creative, (6) dynamic, and (7) independent.

\section{Leadership}

Colquitt et al. define leadership is the use of strength and influence in directing followers' activities to achieve goals (Colquitt et al., 2015). For them leadership is about a person's ability to use strength and influence on his followers to want to carry out their activities to achieve desired goals. Meanwhile Stoner and Freeman say that leadership is art in coordination and motivating individuals and group to achieve the desired end (Stoner \& Freeman, 1995). For them leadership is art in coordination and encouraging individuals or groups in achieving the expected goals. So, leadership means the process of how leaders are imaginatively governing, directing, guiding or influencing others in choosing and achieving certain goals.

Dlamini, said "transformational leadership occurs when the leader motivates, inspires and intellectually encourage subordinates with charismatic behavior and employees follow the steps in achieving organizational goals" (Dlamini, 2017). This means transformational leadership occurs when leaders motivate, inspire and intellectually stimulate subordinates to behave in charismatic ways and employees follow rules in achieving organizational goals. 
By exposing the concept above, it can be synthesized that what is meant by leadership is a person's actions in influencing and directing a person or group of people by recognizing, supporting, training or developing, motivating or inspiring, fostering good relations, protecting and giving feedback to subordinates to be willing to work together in achieving goals set by the organization.

Robbins S.P. define leadership as the ability to influence a group toward the achievement of a vision or set of goals (Robbins, S.P., 2011). For them leadership The ability to influence also presupposes the involvement of other parties, namely followers. It was also said that such leadership could emerge from the middle of the group, but it could also be because it was formally appointed (Robbins, S.P., 2011).

The indicators of leadership are (1) leadership actions in influencing and directing, (2) leadership clarity in delegating tasks, (3) ways to guide and establish and reinforce organizational policies, (4) how to guide its members in carrying out the organization's vision and mission, (5) how to provide input or advice in implementing policies and (6) activities in working both personally and in groups.

\section{METHODOLOGY}

This research was carried out for 1.5 years, starting in December 2016 until May 2018. In accordance with the problems and research objectives to be achieved, this research method uses a survey with a multiple regression analysis approach. Multiple linear regression analysis is the development of simple linear regression analysis where there is more than one independent variable $X$. This analysis is used to see a number of independent variables $\mathrm{X}_{1}, \mathrm{X}_{2}, \ldots \mathrm{X}$ on the dependent variable $\mathrm{Y}$ based on the values of independent variables $\mathrm{X}_{1}, \mathrm{X}_{2}, \ldots \mathrm{X}_{\mathrm{k}}$. The target unit in this study is the middle managerial level employee of the private company. The sample characteristics are (1) managerial employees at the middle manager level; (2) middle level manager employees who have worked in a plantation for a minimum of 5 years of work; (3) middle level manager employees with positions as head of department.

The total population of employees and at the same time as an affordable population are 143 people. To determine sample size, researchers used Slovin's formula technique. The level of precision is set at 0.05 or $5 \%$ of the total population of 143 middle level employees, a sample of 105 people is obtained.

This research was carried out based on the adoption of an existing model, namely "Integrative Model of Organizational Behavior" developed by Colquitt et al. in his book Organizational Behavior (Colquitt et al. 2009b) shown in the following diagram in table 1. In this study there are three variables that will be examined. The three variables consist of work culture variables $\left(\mathrm{X}_{1}\right)$ and leadership $\left(\mathrm{X}_{2}\right)$ as exogenous variables and trust variables as endogenous variables.

Table 1. Operational Variables

\begin{tabular}{|l|l|l|l|}
\hline No. & Variable & Indicator & Reference \\
\hline 1 & Trust & $\bullet$ Assignment of tasks & Rahmani \& Heydari, 2017; \\
& & $\bullet$ Completion of tasks & McShane \& Glinow, 2008; \\
& & - Team cohesiveness & Sureyya, 2017; \\
& & - Effective communication & Luthans, 2011; \\
& & - Idea development & Mullins, 2005 \\
& & - Justice & \\
& & - Responsibility & \\
& & - Support & \\
\hline 2 & Work Culture & - Consistency & Schein, 2004; \\
\hline
\end{tabular}




\begin{tabular}{|c|c|c|c|}
\hline & & $\begin{array}{ll}\text { - } & \text { Discipline } \\
\text { - } & \text { Productive } \\
\text { - } & \text { Responsibility } \\
\text { - } & \text { Creative } \\
\text { - } & \text { Dynamic } \\
\text { - } & \text { Independent } \\
\end{array}$ & $\begin{array}{l}\text { Nawawi, 2003; } \\
\text { Prasetya, 2001; } \\
\text { Osborne \& Plastrik, } 2002\end{array}$ \\
\hline 3 & Leadership & $\begin{array}{l}\text { - Leadership actions in } \\
\text { influencing and directing } \\
\text { - } \text { Leadership clarity in delegating } \\
\text { tasks } \\
\text { - Ways to guide and establish } \\
\text { and reinforce organizational } \\
\text { policies } \\
\text { - How to guide its members in } \\
\text { carrying out the organization's } \\
\text { vision and mission } \\
\text { - How to provide input or advice } \\
\text { in implementing policies } \\
\text { Activities in working both } \\
\text { personally and in groups }\end{array}$ & $\begin{array}{l}\text { Colquitt et al., 2015; } \\
\text { Stoner \& Freeman, 1995; } \\
\text { Dlamini, 2017; } \\
\text { Robbins, S.P., } 2011\end{array}$ \\
\hline
\end{tabular}

This can be seen in the constellation of relations between variables, as can be seen in figure 1 below.

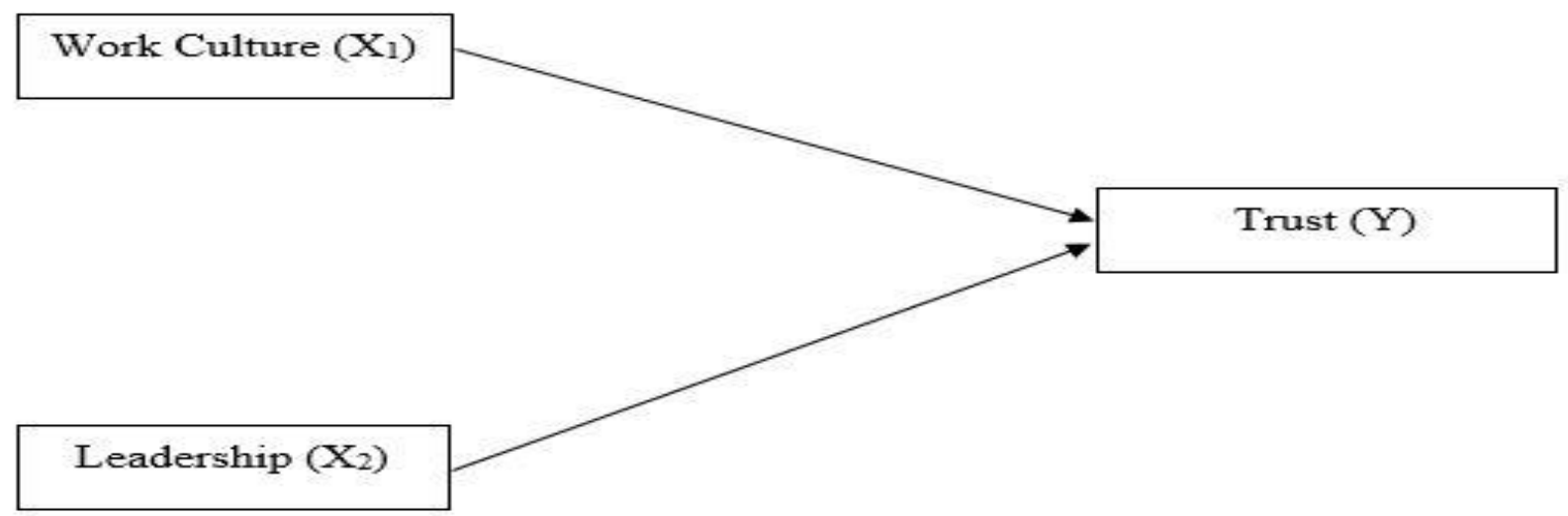

Figure 1 Constellation of Research Problems

Based on the formulation of the problem and the theoretical framework, the research hypothesis can be formulated as follows:

1. There is a positive direct effect of work culture on trust

2. There is a positive direct influence of leadership on trust

3. There is a positive direct effect of work culture and leadership together on trust

\section{RESULT AND DISCUSSION}

Before testing hypotheses, it is necessary to first test the requirements for data analysis including normality test and linearity test. Based on data processing using SPSS 25, the normality test output is obtained as shown in table 2 below. 


\section{Tests of Normality}

Kolmogorov-Smirnov ${ }^{\mathrm{a}}$

Shapiro-Wilk

\begin{tabular}{l|r|r|r|r|r|r} 
& Statistic & \multicolumn{1}{c|}{ df } & \multicolumn{1}{c|}{ Sig. } & Statistic & \multicolumn{1}{c}{ df } & \multicolumn{1}{c}{ Sig. } \\
\hline Y (Trust) &, 061 & 105 &, $200^{*}$ &, 991 & 105 &, 726 \\
\hline $\begin{array}{l}\text { X1 (Work } \\
\text { Culture) }\end{array}$ &, 047 & 105 &, $200^{*}$ &, 983 & 105 &, 189 \\
\hline X2 (Leadership) &, 066 & 105 &, $200^{*}$ &, 989 & 105 &, 564 \\
\hline
\end{tabular}

*. This is a lower bound of the true significance.

a. Lilliefors Significance Correction

From the table 2 above output we see in the Kolmogorov-Smirnov column, it can be seen that the significance value for trust is 0.200 , work culture is 0.200 and leadership is 0.200 . Because the significance for all variables is greater than 0.05 , it can be concluded that the population data on trust, work culture and leadership are normally distributed.

Based on the results of linearity test using SPSS 25 can be seen in the summary of the results of the calculation of linearity test in table 3 below.

Table 3 Linearity Test Between Trust and Work Culture

\begin{tabular}{|c|c|c|c|c|c|c|c|}
\hline \multicolumn{8}{|c|}{ ANOVA Table } \\
\hline & & & $\begin{array}{l}\text { Sum of } \\
\text { Squares }\end{array}$ & df & Mean Square & $\mathrm{F}$ & Sig. \\
\hline \multirow{5}{*}{$\begin{array}{l}Y(\text { Trust) * X1 (Work } \\
\text { Culture) }\end{array}$} & \multirow[t]{3}{*}{ Between Groups } & (Combined) & 8110,840 & 43 & 188,624 & 1,543 &, 059 \\
\hline & & Linearity & 1937,173 & 1 & 1937,173 & 15,847 &, 000 \\
\hline & & Deviation from Linearity & 6173,667 & 42 & 146,992 & 1,203 & 252 \\
\hline & \multicolumn{2}{|l|}{ Within Groups } & 7456,550 & 61 & 122,239 & & \\
\hline & \multicolumn{2}{|l|}{ Total } & 15567,390 & 104 & & & \\
\hline
\end{tabular}

From the table 3 above, the results of linearity tests between trust and work culture can be seen in the ANOVA Table output. It can be seen that the significance value in linearity is 0,000 . Because the significance is less than 0.05 , it can be concluded that between the variables of trust and work culture there is a linear relationship.

Table 4 Linearity Test Between Trust and Leadership

\begin{tabular}{|c|c|c|c|c|c|c|c|}
\hline \multicolumn{8}{|c|}{ ANOVA Table } \\
\hline & & & $\begin{array}{c}\text { Sum of } \\
\text { Squares }\end{array}$ & df & Mean Square & $\mathrm{F}$ & Sig. \\
\hline \multirow{5}{*}{$\begin{array}{l}\mathrm{Y}\left(\text { Trust) }{ }^{*} \mathrm{X} 2\right. \\
\text { (Leadership) }\end{array}$} & \multirow[t]{3}{*}{ Between Groups } & (Combined) & 11555,990 & 49 & 235,837 & 3,234 &, 000 \\
\hline & & Linearity & 978,192 & 1 & 978,192 & 13,412 &, 001 \\
\hline & & Deviation from Linearity & 10577,799 & 48 & 220,371 & 3,021 &, 000 \\
\hline & \multicolumn{2}{|l|}{ Within Groups } & 4011,400 & 55 & 72,935 & & \\
\hline & \multicolumn{2}{|l|}{ Total } & 15567,390 & 104 & & & \\
\hline
\end{tabular}

From the table 4 above, the results of the linearity test between trust and leadership can be seen in the ANOVA Table output. It can be seen that the significance value in linearity is 0.001 . Because the significance is less than 0.05 , it can be concluded that between the variables of trust and leadership there is a linear relationship.

Based on data processing using SPSS 25 the hypothesis test output is obtained as shown in table 5 below. 


\section{Table 5 Results of Hypothesis Test Calculations}

\begin{tabular}{|c|c|c|c|c|c|c|}
\hline \multirow{3}{*}{\multicolumn{2}{|c|}{ Model }} & \multicolumn{3}{|c|}{ Coefficients $^{\mathbf{a}}$} & \multirow[b]{3}{*}{$\mathrm{t}$} & \multirow[b]{3}{*}{ Sig. } \\
\hline & & \multicolumn{2}{|c|}{$\begin{array}{c}\text { Unstandardized } \\
\text { Coefficients }\end{array}$} & \multirow{2}{*}{$\begin{array}{c}\text { Standardized } \\
\text { Coefficients } \\
\text { Beta } \\
\end{array}$} & & \\
\hline & & $\mathrm{B}$ & Std. Error & & & \\
\hline \multirow[t]{3}{*}{1} & (Constant) & 44,844 & 11,973 & & 3,745 & ,000 \\
\hline & $\begin{array}{l}\text { X1 (Work } \\
\text { Culture) }\end{array}$ & ,349 & ,096 & ,329 & 3,626 &, 000 \\
\hline & X2 (Leadership) &, 186 &, 079 & ,214 & 2,362 &, 020 \\
\hline
\end{tabular}

a. Dependent Variable: Y (Trust)

From the coefficients table 5 obtained from the results of hypothesis testing using the SPSS 25 program obtained the sig value for the work culture of 0.000 . Because the value of sig $=0.000<0,05, \mathrm{H}_{0}$ is rejected, thus it can be concluded that the work culture has a positive effect on trust, meaning that the higher the work culture, the more confidence is predicted to increase. Likewise, the value of sig for leadership is 0.020. Because the value of sig $=0.020<0.05, \mathrm{H}_{0}$ is rejected, thus it can be concluded that leadership has a positive effect on trust, meaning that the higher the leadership, the more trust is predicted to increase.

Based on the processing of data using SPSS 25, the hypothesis test output is obtained from the influence of work culture and leadership together on trust as shown in table 6 below.

Table 6 Results of Calculation of Hypothesis Tests Effect Together Work Culture and Leadership Against Trust

\begin{tabular}{|c|c|c|c|c|c|c|}
\hline \multicolumn{7}{|c|}{ ANOVA $^{\mathrm{a}}$} \\
\hline \multicolumn{2}{|l|}{ Model } & $\begin{array}{l}\text { Sum of } \\
\text { Squares }\end{array}$ & df & Mean Square & $\mathrm{F}$ & Sig. \\
\hline \multirow[t]{3}{*}{1} & Regression & 2643,972 & 2 & 1321,986 & 10,434 &, $000^{\mathrm{b}}$ \\
\hline & Residual & 12923,419 & 102 & 126,700 & & \\
\hline & Total & 15567,390 & 104 & & & \\
\hline
\end{tabular}

a. Dependent Variable: Y (Trust)

b. Predictors: (Constant), X2 (Leadership), X1 (Work Culture)

From the ANOVA table 6 obtained from the results of hypothesis testing using the SPSS 25 program obtained a sig value of 0,000 . Because the value of $\operatorname{sig}=0,000<0,05$, then $\mathrm{H}_{0}$ is rejected, thus it can be concluded that work culture and leadership have a positive effect on trust, meaning that the higher the work culture and leadership the more trust is predicted to increase.

Based on data processing using SPSS 25, the output correlation coefficient and coefficient of determination were obtained from the hypothesis test of the influence of work culture and leadership together on trust as shown in table 7 below. 


\section{Table 7 Results of Calculation of Correlation Coefficients and Determination} Coefficients

\begin{tabular}{cc|c|c|c} 
& & \multicolumn{2}{c}{ Model Summary } \\
Model & $\mathrm{R}$ & R Square & $\begin{array}{c}\text { Adjusted R } \\
\text { Square }\end{array}$ & $\begin{array}{c}\text { Std. Error of } \\
\text { the Estimate }\end{array}$ \\
\hline 1 &, $412^{\mathrm{a}}$ &, 170 &, 154 & 11,256 \\
\hline
\end{tabular}

a. Predictors: (Constant), X2 (Leadership), X1 (Work

Culture)

From the Model Summary table 7 above, obtained from the results of data processing using the SPSS 25 program, it can be seen that the correlation coefficient $(\mathrm{R})$ is 0.412 . Because the correlation coefficient of 0.412 is located between $0.400-0.599$, it can be concluded that there is a moderate relationship between the variables of work culture and leadership together with trust.

Based on the output obtained the number $\mathrm{R}^{2}$ ( $\mathrm{R}$ Square) of 0.170 or $17.0 \%$. This shows that the percentage of the influence of the independent variable (work culture and leadership) on the dependent variable (trust) of $17.0 \%$ or the variation of the independent variables used in the model (work culture and leadership) is able to explain $17.0 \%$ of the dependent variable variation (trust) while the remaining $83.0 \%$ is influenced or explained by other variables not included in this research model.

Based on the results of the analysis and hypothesis testing indicate that the three hypotheses proposed in this study are proven. This implies that in general at PT. Astra Agro Lestari Tbk., There is a direct influence: (1) work culture towards trust; (2) leadership towards trust; (3) work culture and leadership together towards trust.

In detail, the discussion of the results of the analysis and testing of the research hypothesis is described as follows:

\section{Hypothesis Test Results Effect of Work Culture $\left(X_{1}\right)$ on Trust (Y)}

The work culture in principle is related to the system of values, perceptions, behaviors and beliefs held by each individual employee about the meaning of work and reflection in activities to achieve organizational goals. These aspects of work culture must be managed well in an organization. Likewise with the organization PT. Astra Agro Lestari Tbk. as one of the companies engaged in the business of oil palm plantations in Indonesia.

In this study, it is in line with the hypothesis to prove that the work culture influences trust in PT. Astra Agro Lestari Tbk. From the results of the verification research, it turns out that work culture has a positive direct effect on trust. This can be proven from hypothesis testing which results in the results of hypothesis testing using the SPSS 25 program obtained by the sig value for the work culture of 0,000 . Because the sig value $=$ $0,000<0,05, \mathrm{H}_{0}$ is rejected, thus it can be concluded that the work culture has a positive effect on trust.

This is supported by the opinions of several experts as outlined in the theoretical framework represented by Robbins \& Judge, who stated that three parts of input from the socialization process will be complete when new members are comfortable with their organization and work. They have included and accepted the norms of the organizational culture and their work groups, who are confident in their competencies and feel trust and respect for their coworkers. They understand that systems are not just their jobs but rules, procedures and are well received informally. In the end they know what is expected of them and what criteria will be used to measure and evaluate their work.

This is supported by research Chang's research discusses the importance of affective relationships, their many benefits and the role of various forms of influence, such as trust, empathy and consideration. Theoretical considerations about affective relations frame the empirical evidence gathered from examining Chinese and Zambians working together in two companies, one belonging to China and the other belonging to Zambia. With the 
argument that business friendship combines both role and influence. This study discusses how Chinese and Zambian informants in the company integrate it into their professional lives easily by expressing and using the explicit benefits of business friendship to their advantage (Chang, 2013). Research Angelle et al. also concluded that there was a correlation between collective trust and efficacy, $r(166)=.68, p<.01$ (Angelle et al, 2011). Haugen's research concluded that organizational culture is an influencer of trust (Haugen, 2010).

Of the seven work culture indicators, there are four indicators that need to be improved, namely productive, creative, dynamic and independent indicators. These four indicators need to be improved because with the increase in these indicators certainly can contribute to increasing trust. While the indicators that are good, namely indicators of hard work, discipline and responsibility, the leadership at PT. Astra Agro Lestari Tbk. needs to take care of them so that these indicators are maintained well.

Associated with reality in the field, researchers argue that even though PT. Astra Agro Lestari Tbk. has a mechanism in managing work culture as stated by the experts above including in taking policies related to work culture that consider the perspective of employees but in implementation there are still gaps as shown in the description of research data. Evidence that PT. Astra Agro Lestari Tbk. has managed its corporate culture well, PT. Astra Agro Lestari Tbk. has a corporate culture consisting of honest and responsible, triple $\mathrm{S}$, fanatic, caring, control, repair and innovation and intention.

Based on empirical evidence, the findings of this study indicate that work culture is one of the most important variables and has a direct effect on the trust variable. Based on this empirical evidence, it can be said that this finding shows that work culture is one of the most important variables and has a direct effect on trust.

\section{Hypothesis Test Results Effect of Leadership $\left(\mathbf{X}_{2}\right)$ on Trust $(\mathbf{Y})$}

Judging from the theory or concept of leadership is basically a person's actions in influencing and directing a person or group of people by recognizing, supporting, training or developing, motivating or inspiring, fostering good relations, protecting, and giving feedback to subordinates to work together for achieve the goals set by the organization. The factors that support leadership must be managed well in an organization. Likewise with the organization of PT. Astra Agro Lestari Tbk. as one of the companies engaged in the business of oil palm plantations in Indonesia.

In this study in line with the hypothesis to prove leadership influences trust in PT. Astra Agro Lestari Tbk. From the results of the verification research, it turns out that leadership has a positive direct effect on trust. This can be proven from the hypothesis testing which results in the results of hypothesis testing using the SPSS 25 program obtained by the sig value for work culture of 0.020 . Because the sig value $=0.020<0.05$, $\mathrm{H}_{0}$ is rejected, thus it can be concluded that leadership has a positive effect on trust.

This is supported by the opinion of some experts as outlined in the theoretical framework represented by Robbins \& Judge (2011) which states that trust is first a trait that must be attached to leadership, leadership without trust means disaster (Robbins \& Judge, 2011). As great as any leader without gaining the trust of members there will be no meaning (Robbins \& Judge, 2011). The results of this study were also supported by the research of Lin and Hsiao (2014) which showed a significant relationship between transformational leadership and trust with a correlation coefficient of $r=0.77$ at $p<0.01$ (Lin \& Hsiao, 2014).

This research is also in line with the research conducted by Mathebula (2010) about the influence of leadership on trust. His research concerns the relationship between employee commitment, leadership, human resource management and trust in the organization. In his research on 246 civil servants in South Africa from various agencies, it was found that there was a strong relationship between leadership and trust (Mathebula, 2010). Research Angelle et al. also concluded that a correlation between teacher trust and leadership was found $\mathrm{r}(166)=.50, \mathrm{p}<.01$ (Angelle et al, 2011). 
Of the six six indicators of leadership, there are three indicators that need to be improved, namely indicators of delegating, implementing policies and activities at work. These three indicators need to be improved because with the increase in these indicators, they certainly can contribute to increasing trust. While the indicators are good, namely indicators affect, organizational policies and socialize the vision and mission of the organization, leaders at PT. Astra Agro Lestari Tbk. need to take care of it so that this indicator is maintained well.

Associated with reality in the field, researchers argue that even though PT. Astra Agro Lestari Tbk. already has a mechanism in managing leadership as stated by the experts above including in taking policies related to leadership that consider the perspective of employees but in its implementation there are still gaps as shown in the description of research data. Evidence that PT. Astra Agro Lestari Tbk. has managed leadership well, PT. Astra Agro Lestari Tbk. in selecting candidates for its head of education, has carried out psychological tests by using the services of consultants from outside the company to select candidates for their Afdeling Heads so that Afdeling candidates will be elected with good leadership . Likewise, training related to leadership has been conducted regularly.

Based on empirical evidence, these findings indicate that leadership is one of the most important variables and has a direct effect on the trust variable. From the description of the theory above and based on empirical evidence carried out in this study, it is evident that leadership has a direct positive effect on trust.

\section{Hypothesis Test Results Effect of Leadership (X3) on Trust (Y)}

From the results of hypothesis testing shows that there is an influence of work culture and leadership together on trust with the regression equation $\hat{Y}=44,844+0,349 X_{1}+0,186$ $\mathrm{X}_{2}$ with the sig value of the ANOVA table in table 5 the results of the calculation of the hypothesis test influence together work culture and leadership on trust obtained from the results of hypothesis testing using the SPSS 25 program obtained sig value of 0,000 . Because the value of sig $=0.000<0.05$, then $\mathrm{H}_{0}$ is rejected, thus it can be concluded that work culture and leadership have a positive effect on trust, meaning that the higher the work culture and leadership the more trust is predicted to increase.

The multiple correlation coefficient between work culture and leadership together towards trust of 0.412 shows that each increase in work culture and leadership scores together will increase trust. The results obtained for the coefficient of determination $\left(\mathrm{R}^{2}\right)$ from the influence of work culture and leadership together on trust amounted to 0.170 $(17.00 \%)$. This means that $17.00 \%$ of trust is the result of the workings of work culture and leadership together, while $83.00 \%$ is contributed by other variables that have a relationship with trust but are not examined in this study. Thus it can be seen, if the company has a good work culture and is led by leaders who have strong leadership then together will be able to increase trust in the organization.

\section{CONCLUSION}

Based on the analysis above, the findings in this study are as follows: there is a positive direct effect of work culture on trust, meaning that if the work culture increases, it is predicted that trust will also increase; there is a positive direct effect of leadership on trust, meaning that if leadership increases, it is predicted that trust will also increase; there is a positive direct influence along with work culture and leadership towards trust, meaning that if the work culture and leadership together increase, it is predicted that trust will also increase. 


\section{REFERENCES}

Angelle et al. (2011). Increasing organizational effectiveness: An examination of teacher leadership, collective efficacy, and trust in schools.

Chang, J. (2013). Affect, Trust and Friendship: A Case Study of Chinese and Zambian Relationships at the Workplace. International Journal of Business Anthropology, 4(1), 38.

Colquitt, Jason A., Jeffery A. LePine., and M. J. W. (2009). Organizational Performance and Commitmen in the Workplace. New York: McGraw-Hill Irwin.

Colquitt, J. A. et al. (2015). Organizational Behavior: Improving Performance and Commitment in the Workplace. New York: McGraw-Hill.

Dlamini, N. N. N. et al. (2017). The impact of transformational leadership style on organisational commitment in the hospitality industry. African Journal of Hospitality, Tourism and Leisure, 6(3), 3.

Haugen. (2010). Determining the Relationship and Influence Organizational Culture has on Organizational Trust. University of Nebraska, Lincoln. Retrieved from http://digitalcommons.unl.edu/aglecdiss/5

Luthans, F. (2011). Organizational Behavior: an Evidence-Based Approach (12th ed.). New York: McGraw-Hill.

Mathebula. (2010). Modelling the Relationship Between Organizational Commitment, Leadership Style, Human Resource Management Practices, and Organizational Trust. University of Pretoria. Retrieved from http://upetd.up.ac.za

McShanes and Von Glinow. (2008). Organizational Behavior. New York: McGraw-Hill.

Mullins, L. J. (2005). Management and Organizational Behavior. New Jersey: Prentice Hall.

Nawawi, H. (2003). Manajemen Sumber Daya Manusia. Yogyakarta: Gadjah Mada University Press.

Ndraha, T. (1997). Pengantar Teori Pengembangan Sumber Daya Manusia. Bandung: Rosdakarya.

Osborn \& Plastrik. (2002). Manajamen Sumber Daya Manusia. Yogyakarta: BPFE.

Prasetya, T. (2001). Manajemen Sumber Daya Manusia. Jakarta: Bumi Aksara.

Rahmani, S., \& Heydari, M. (2017). Investigating of Trust and Perceived Organizational Support Effects on Organizational Commitment in Educational Organizations , using Structural Equation Modeling and Partial Least Squares Model. International Review of Management and Marketing, 7(2), 384-389.

Robbins, S.P., \& T. A. J. (2011). Organizational Behavior. New Jersey: Pearson Prentice Hall.

Schein, E. (2004). Organizational Culture and Leadership. San Fransisco: John Wiley \& Sons, Inc.

Stoner, J. A. . and F. E. (1995). Management. New Jersey: Prentice Hall.

Sureyya, C. S. (2017). Role of Culture on the Relationships between Trust, Commitment and Corporate Citizenship. Revista de Cercetare [i Interven]Ie Social, 59, 118-135. 